\title{
WHICH EDUCATIONAL DANCE PROGRAMS CAN BE USED TO IDENTIFY CHILDREN'S TALENTS
}

\author{
Elindra Yetti ${ }^{1 *}$, Erie Siti Syarah ${ }^{1}$, Ayu Niza Machfauzia ${ }^{2}$ \\ ${ }^{1}$ Universitas Negeri Jakarta, Indonesia \\ ${ }^{2}$ Universitas Negeri Yogyakarta, Indonesia \\ *e-mail: elindrayetti@unj.ac.id
}

\begin{abstract}
Education will be more meaningful if it is in accordance with children's talents and development. If talents can be recognized from an early age, it will be easier for children to reach the gates of success. This study aims to discuss educational dance programs that facilitate the identification of early childhood dance talents. This study used a qualitative method with data collection through observation, interviews, video documents, and reflection journals. The study was conducted on fifteen students aged 5-6 years in a kindergarten in the Special Capital Region of Jakarta. Findings of the study show that educational dance activity programs can make it easier for teachers and parents to identify early childhood dance talents. The audio-visual activities in the process of exploring dance movements make it easier for teachers and parents to identify early childhood dance talents compared to other movement stimuli. New approach to identify children's dance talents that can be used as a guide by teachers and parents in identifying and developing children's dance talents from an early age.
\end{abstract}

Keywords: audio, audio visual, dance talent identification, early childhood, educational dance program, visual.

\section{PROGRAM TARI EDUKATIF MANA YANG DAPAT DIGUNAKAN UNTUK IDENTIFIKASI BAKAT TARI ANAK}

\begin{abstract}
Abstrak: Pendidikan akan lebih bermakna apabila sesuai dengan bakat dan perkembangan anak. Bila bakat dapat diketahui sejak dini akan lebih mudah mengantarkan anak meraih gerbang kesuksesan. Penelitian ini bertujuan untuk membahas program tari pendidikan yang memudahkan identifikasi bakat tari anak usia dini. Penelitian menggunakan metode kualitatif, dengan pengumpulan data melalui observasi, wawancara, dokumen video, serta jurnal refleksi. Penelitian dilakukan pada lima belas siswa usia 5-6 tahun di salah satu Taman Kanak-Kanak DKI Jakarta. Hasil penelitian ini menemukan tentang program kegiatan tari pendidikan yang dapat memudahkan guru dan orangtua untuk mengidentifikasi bakat tari anak usia dini. Kegiatan audio visual dalam proses eksplorasi gerak tari memudahkan guru dan orang tua dalam mengidentifikasi bakat tari anak usia dini dibanding stimulus gerak yang lain. Pendekatan baru dalam mengidentifikasi bakat tari anak yang dapat dijadikan panduan guru dan orang tua dalam menemukan dan sekaligus mengembangkan bakat tari anak sejak dini.
\end{abstract}

Kata Kunci: audio, audio visual, identifikasi bakat tari, anak usia dini, program tari pendidikan, visual.

\section{INTRODUCTION}

Delayed identification of dance talents in early childhood is a deprivation or providence for the child, parents, national needs, or policy makers (Baumol, Jeffri, \& Throsby, 2006; Burns \& Harrison, 2009). Teachers and parents expect to know the results of dance talent identification that can give them inspiration and adequate knowledge in the process of the development of the children's talents (GarcesBacsal, 2013). Information obtained from such talent identification can be used to nurture the children's talents maximally so that it can support their achievement.

It has long been assumed that children's dance talents can be detected from their behavour since childhood (in the implicit theory). However, this has not been supported by empirical research that ascertains whether the physical and characteristic skills performed by children with dance talents are born, trained, or produced by the interaction of the two (Chua, 
2014). Teachers and parents frequently avoid determining the method of developing children's talents solely assuming their born dexterity or deficiency. This gives difficulties to teachers and parents in broadening their psychological skills to effectively motivate and support their children.

The study in dance identification and development by Aujla, Nordin-Bates, Redding, \& Jobbins (2014) states that, in order to understand optimally how to develop dance talents as early as possible, an inter-disciplinary study is needed, which consists of the combination among physical factors and psychological characteristics, including children's thoughts and perspectives of commitments, creativities, and cultures. Results of this study emphasize the fact that commitment over an activity is an important part of a talent development process.

Some important features in the identification of dance talents from previous studies include, among others, the importance of the relevance of others in a dance career, the detection of dance talents, and the use of the three-phase career proposed by Bloom in the talent domains (Van Rossum, 2001). The study of literature by Walker, Nordin-Bates, \& Redding (2010) uses a systematic approach to analyze dance talents to make it possible for researchers and educators to determine what talents are, how the components are involved, and what is the best way to develop them optimally.

A dance talent is commonly seen as something that can be recognized intuitively, but that it is not easy to define. Without a systematic study on dance talents, it is truly difficult to understand the best way to develop them in a training environment. The concept of talents can be differentiated into two, namely talent identification and talent development. Talent identification refers to the recognition of the individual's sills and potentials; meanwhile, talent development refers to the conditions that facilitate potentials to develop (Aujla et al., 2014). In the same way, in talent assessment, Warburton (2002), new approaches are used in talent assessment in dance and educational dance to include the specific, contextual, and longitudinal domains. Meanwhile, the study by Chua (2015) appraised how much support is given to the talented children in the different phases of their dance talent development.
Another study that carried out screening over Talent Beyond Words, New York, to identify dance talents used an observation model directed to economically and academically deprived children (Baum, Owen, \& Oreck, 1996). The observation can be used not only by professional artists in dance, but it can also be used by beginners, teachers, and parents. Talent identification made on certain criteria has been a general method used by educational services for talented children to appraise the children. As a part of a national talent identification program, one is conducted by UNK (New Generation Centre, Hongarian Talents Program, 2016-2020). The instrument for competency assessment using the matrix style, called TalentTiles, is aimed at gathering data on teachers' scale ratings that is more realistic and reliable for use in identifying students' talents. The instrument needs a very short time, less than two minutes per student, to complete since it focuses on behavioral characteristics, assesses school-related elements, is concerned with general competencies in specific domains (such as ability, motivation, etc.), and it has low correlation co-efficient among the items (Klein \& Fodor, 2019).

Few studies have been done on identifying and developing children's dance talents in program activities in educational dances for children of the early ages. Educational dances for early childhood can facilitate learning at school and have many relations with academic subjects. Dancing is an integral part of education and children's development. Educational dances can build relationship between the mind and body during the movement of the dance (Giguere, 2011). Seeing that dance movements can create positive support and stimuli for children in their developmental process and their movement energy, this can be adopted as a fundamental basis in educational dances.

The difficulty in identifying dance talents since early childhood has indeed become a problem for teachers and parents because of a lack in guidelines. Delay has also become a problem on the part of the Government as the policy maker in handling such rare human resources as dance talents. The present study, therefore, is intended to discuss key findings in educational dance programs that will make it easy for the identification of the dance talents of the early childhood children. The researchers 
also hope that, in future studies, new approaches are also developed in identifying children's dance talents that can be used as a guideline for teachers and parents to identify and develop children's dance talents since very early in their childhood.

\section{METHOD}

This study used a qualitative research method involving fifteen children aged 5-6 years in a kindergarten in Jakarta. Data collection was carried out by observation, interviews, video documentation, and reflective journals. To obtain data about dance education activities carried out by the teacher and about the expression of children's movements when the teacher directs these activities, researchers make observations for one semester. Interviews with Kindergarten teachers are used as a data source for various dance education activities, which are expected to facilitate the identification of children's dance talents. Researchers added data to provide completeness of information from video documentation about educational dance activities. Meanwhile, reflective journals were obtained from teachers who had experience teaching dance in early childhood education institutions from 2006 to 2017 as a source of data for the development of children's dance talents during the learning process that had been carried out.

Data were analyzed using the qualitative model of Miles, Huberman, \& Saldana, (2014). Data analysis was accomplished in the following phases of: 1) data condensation, 2) data presentation, and 3) conclusion drawing. Data trustworthiness was ensured by method triangulation; i.e., comparing the data obtained from the four data collection methods of field observation, interview transcripts, notes from video documentation, and information from the reflective journals. Meanwhile, validation of data was done through a focused group discussion supervised by experts from childhood lecturers, dance practitioners, and childhood teachers.

\section{FINDINGS AND DISCUSSION Findings}

The main findings of the study are kinds of educational dance activities that make it easy for teachers and parents to identify dance talents of children of the childhood ages. Each finding has been analyzed using the triangulation methods of data collection which can be labeled as field observation notes (FON), field interview notes (FIN), video documentation notes (VDN), and reflective journal notes (RJN). Based on the data analyses, the summary of the research findings that can be seen in Table 1 .

Table 1. Summary of Data Analyses

\begin{tabular}{|c|c|c|}
\hline $\begin{array}{c}\text { Educational Dance } \\
\text { Activity }\end{array}$ & Data Description & Conclusion \\
\hline $\begin{array}{l}\text { 1. Audio } \\
\text { (exploration of } \\
\text { movement by } \\
\text { listening to music) }\end{array}$ & $\begin{array}{l}\text { Movement technique cannot be seen clearly. Elastic movement } \\
\text { is less seen. Body movement strength is less seen. Ability to } \\
\text { remember movement is less seen. Match of movement and } \\
\text { tempo is good. Internalization of movement is not seen, but } \\
\text { facial expression is good. Child looks excited to dance together } \\
\text { with friends. Child can produce new movement. Motivation to } \\
\text { move is seen (FON, FIN, VDN, RJN). }\end{array}$ & $\begin{array}{l}\text { Development of child's dance talents is not } \\
\text { seen since child is more focused on listening to } \\
\text { narration while moving. Movement elasticity } \\
\text { can be seen only on the hands while movement } \\
\text { on other parts of the body is not (no movement } \\
\text { coordination). }\end{array}$ \\
\hline $\begin{array}{l}\text { 2. Visual } \\
\text { (exploration of } \\
\text { movement by } \\
\text { watching activities } \\
\text { in the environment/ } \\
\text { watching the } \\
\text { video) }\end{array}$ & $\begin{array}{l}\text { Movement technique cannot be seen clearly. Elastic movement } \\
\text { is less seen. Body movement strength is less seen. Ability to } \\
\text { remember movement is good. Match of movement and tempo } \\
\text { is less seen. Internalization of movement is not seen, but facial } \\
\text { expression is good. Child looks excited to dance together with } \\
\text { friends. Child can produce new movement. Motivation to } \\
\text { move is seen (FON, FIN, VDN, RJN). }\end{array}$ & $\begin{array}{l}\text { Development of child's dance talents is not } \\
\text { seen; child moves as if playing. Ability of } \\
\text { musicalization is not seen since, besides not using } \\
\text { music, movement is not seen that is led by tempo. }\end{array}$ \\
\hline $\begin{array}{l}\text { 3. Audiovisual } \\
\text { (exploration of } \\
\text { movement by } \\
\text { listening to music } \\
\text { and observing what } \\
\text { can be found in the } \\
\text { environment) }\end{array}$ & $\begin{array}{l}\text { Movement technique can be seen clearly. Elastic movement } \\
\text { is seen well. Body movement strength is seen. Ability to } \\
\text { remember movement is good. Match of movement and } \\
\text { tempo is seen. Internalization of movement is seen, and facial } \\
\text { expression is good. Child looks excited to dance together with } \\
\text { friends. Child can produce new movement. Motivation to } \\
\text { move is seen (FON, FIN, VDN, RJN). }\end{array}$ & $\begin{array}{l}\text { Development of child's dance talents is clearly } \\
\text { seen; child moves imitating animals' movements, } \\
\text { following the rhythm of the music, able to manage } \\
\text { energy, and body movement looks elastic. } \\
\text { Child looks focused and excited in making } \\
\text { movements; despite the repeated dance } \\
\text { movements, child remains excited. Ability to } \\
\text { remember movements is good since the music is } \\
\text { in accord with animal themes. New movements } \\
\text { emerge. }\end{array}$ \\
\hline
\end{tabular}


The three educational dance activities are used to identify dance talents; namely movement exploration through audio, visual, and audiovisual. However, the audiovisual activities, which combine music listening and moving stimulated by what can be seen around, seem to be the best mode since these audiovisual activities help teachers and parents to identify dance talents of the childhood-age children. Using the suitable educational dance program helps children in performing their movements well which in turn helps in identifying children's dance talents.

\section{Educational Dance Activities Using Audio}

In the audio activities of the educational dance, the exploration of the dance movement is accompanied by music. The music is selected to be in line with the characteristics of the children, and the ones liked by the children. This helps in stimulating the children to move in the accompaniment of the music. From the results of the data analyses, the following statements can be presented.

(1) When the audio program of the educational dance is carried out in the art centre of the kindergarten or in the classroom, each of the fifteen children shows a different bodily awareness as they are asked to move under the accompaniment of the musical rhythm (VDN).

(2) A number of children move on assuming random movement following the sound like the music. The movements emerge in the forms of small skipping that does not show dance movement techniques. On the other hand, a number of the children do not seem to be aware that they move in the stimulation of rhythm to the music (FIN, FON).

(3) Children who can give good movements tend to move more vivaciously. They are able to move in close agreement with the rhythm to the music (FIN, FON).

(4) When they are asked to move independently without examples from the teacher, the children are able to move in accordance with the rhythm to the music. They are able to understand instructions; such as when they are asked to jump forward twice, they are able to do it in accordance with the music sound (FIN, FON).
(5) Quote from reflective journals shows that children with a high bodily awareness tend to make a better bodily posture and move livelier and in accordance with the directions or instructions given. These children tend to enjoy music rhythm more and move in accordance with the rhythm beats (RJN).

From the video documentation (during the audio sessions of the educational dance activities), it can be seen that talented children have a different bodily awareness than other students, in line with findings in the interviews with teachers who children with high bodily awareness, especially when they listen to music, are able to move following the beats to the music rhythm without directions from the teacher. Findings in the observation data show that children with a high bodily awareness can move more dynamically, supporting findings from the video analyses and interview transcripts. Movement awareness can be raised by the stimulation from the music and can be modified through the teacher's instructions in harmony with the rhythm to the music.

\section{Educational Dance Activities Using Visual}

In the visual activities of the educational dance, the exploration of the dance movement is made by looking at whatever found throughout the environment around the children. In this case, the children move imitating the movements of animals. The results from the data analyses, the following statements can be presented.

(1) Few children are seen to have elasticity and techniques of good movements; in the video, it can often be seen the children play jokes with each other. From the video, it can be seen that many of the children use hand movements, and a number of the children are able to move their fingers elastically and hands smoothly. However, it is seen that children do not move all parts of the body such as the feet, heads, and bodies (VDN).

(2) Some children dance by imitating their friends' movements so that, when their friends make the wrong movements, they make the wrong movements too. This often happens in children who are not too enthusiastic in joining the activities. They become unfocused. In other times, this happens when the teacher stops giving the 
examples of movements, and the children are not able to make the movements (FON, FIN).

(3) Few children do not have good adaptive abilities in order to perform the dance; on the contrary, many feel shy to dance. However, many who have high enthusiasm tend to be more diligent than the others and quicker to adapt to new experiences (FON, FIN).

(4) From the reflective journals, it can be noted that children with high physical strengths generally also have strengths in remembering movements and in focusing. These children tend to enjoy all the dancing activities; however, when the activities are conducted without music, some of these children look bored and seem to lose strengths. It seems that music brings strengths to the children in order to maintain their physical strengths (RJN).

From the finding of the video documentation during the activities using visual, it can be seen that children who are identified as having dance talents tend to have fluidity and vivacity in their movements, especially when music is played in the activities. This is in line with results from interviews with the teacher and direct observation. The teacher states that children with dance talents tend to have high enthusiasm so that they do not have obstacles in imitating various movements that they see. High enthusiasm and interest in the dance activities make the children tend to move smoothly, elastically, and vivaciously. However, children's enthusiasm must often times be established by the appropriate stimuli, such as music that children like. It can be concluded that these findings indicate that children who move with stimuli in the environment tend to lose their enthusiasm if there is no music to accompany them to give them a cheerful and happy atmosphere.

\section{Educational Dance Activities Using Audio- Visual}

In the audio-visual activities of the educational dance, the exploration of the dance movement is made by using music stimulus and movement stimuli from what can be seen from around the environment. In this study, it is a combination of animals' movement and music accompaniment. From the results of the data analyses, the following statements can be presented.

(1) The video documentation shows that most of the children have good physical strengths in their bodily movements. When they jump to the left and right, there is the distribution of strengths in the movements of the head, body, hands, and feet. Children who have high elasticity seems to have a dance talent. Children who can perform a pose split well have been recorded as having smooth ability movement shifts from one movement to another. Their ability to memorize movements can be clearly seen. Most of the children memorize the sequences of the movements while following the rhythm from the music (VDN).

(2) The children's sensitiveness and ability to relate movement to music seem to be high. In other words, they have high musicality. In the video documentation, it appears that most children have a high musical sensitivity; they seem to have natural responses to music. When moving, they have the right movements in accord with the beats of the music rhythm. The children seem to enjoy the melody of the song, and their bodies move synchronously with the dynamics of the song (VDN).

(3) The children seem to have good elasticity when they make the movement of jumping to the floor; they can land smoothly and without being hurt. They can make a turning around movement while still maintaining balance and moving their hands smoothly (FON, FIN).

(4) When offered with a new dance form, or new movements, most of the children look excited; they seem to be enthusiastic with new things. However, not many of the children like and are open to new experiences. The children who are able to express their feelings using movements or facial expressions are caused more by their ability to understand the meaning of dances. They can show their expressions even stronger when the dances are accompanied by music with songs with lyrics they know well (FON, FIN).

(5) From the reflective journal notes, it can be seen that children with a strong ability in memorizing look relaxed in their movements, 
move elastically and smoothly, and enjoy the dancing activities. They are able to shift from one movement pattern to another in accordance with the rhythm beats of the music. The children also can remember the formation as to where they should stand in the line and where they should go when they change places. They are able to memorize the sequences of the movements when they like the dances, the music, the movements, and even the costumes. One important finding is that children who are good in remembering the sequences of the dance movements are usually children who are good at academic work (RJN).

It can be seen that educational dance activities using visual stimuli and music with favorite songs can stimulate children's abilities in dance movements. This stimulation also makes it easier to identify children's dance talents, which include movements in accordance with music, coordination of body movements, and expression of movements. An important finding in this section is that the use of appropriate stimuli can show a child's dancing talent as described in statement (4). Children who have a talent for dancing are able to express their feelings in the form of movements or facial expressions, because they understand the meaning of the lyrics of the songs that accompany their dance (listed in field observation notes and interviews with teachers). This is also supported by the data from the teacher's reflective journal notes. Gifted children with dance have a good understanding of the meaning of dance, the meaning of song lyrics that accompany the dance, and easily memorize the sequence of movements in dance choreography.

\section{Discussion}

The findings of this study offer a solution to teachers and parents in identifying children's dance talents from an early age regarding motion stimulation or audiovisual activities in dance education activities. Movement exploration activities are determined by movement stimulation that makes possible the practices of abilities in the modification of movements; without the movement stimuli it is not possible to produce new movements as a result of exploration (Martín, Ric, \& Hristovski, 2015).

Talent development has now become an important topic in academic, sport, and art research (Walker et al., 2010). Teachers and parents of childhood children need guidance to identify children's dance talents since the early development of the children. Academic research is expected to bring about guidelines for identifying childhood children's dance talents that are reliable to provide information about phenomena of these talents. Although the general opinion is for the inclination that talents are considered as a born or genetic component of skill development, and although there still persists a big question as to which component is more dominant, talents remain a difficult thing to define (Lidor, Côté, \& Hackfort, 2009). It is in this relation that findings of this study that state that identifying dance talents can be done by audio, visual, and audiovisual activities to explore children's movement awareness can be used as a guide to dance talent identification. This is shown by the results of the analyses of the research data from the video documentation, observation, interviews, and reflective journals in the educational dance activities in the childhood classes that provide a number of points to be taken into consideration by teachers and parents in giving rationales for the further development of the children.

One of the important findings in identifying children's dance talent is related to the use of audiovisual motion stimuli, especially in cases where teachers and parents find that children have good body movement awareness. This is also related to the musical intelligence and kinesthetic intelligence of children who go hand in hand in harmony. Children's musical intelligence makes children move in harmony with music beats (Williams, 2018) and children's kinesthetic intelligence makes them able to move smoothly and easily. This is evidenced by research that measures range of motion (ROM), showing that a dancer's talent has a greater range of motion (known as hypermobility) than non-dancers (McCormack, Briggs, Hakim, \& Grahame, 2004).

Inclusive in the bodily movement awareness is when children have elasticity and bodily strength that is greater than their peer does, and talented children move more elastically and take longer time in their movement that needs bodily strengths. The theory of children's movement in the optimal level of elasticity or 
range of motion (ROM) shows that the children have the potentials to become professional dancers (Walker et al., 2010). Children are said to have a talent for dancing if they show great flexibility in making movements, such as kissing the knees, or are generally able to move joints (such as hips, back, and ankles) easily through a whole series of movements. Moving the outer hips in rotation is an important indicator of dance talent and may be improved through practical training (Steinberg, Hershkovitz, Peleg, Dar, Masharawi, Heim, \& Siev-Ner, 2006). When teachers or parents identify the child's muscle strength, such as when they make strong jumping and landing movements, or move energetically and don't tire easily, they will see indicators of the ownership of the child's dancing talent. This suggests that muscle strength is likely to be a strong indicator of dancing talent. However, different muscle movements may require different levels of strength (Walker et al., 2010), as it is known that certain dancing skills are associated with certain muscles (Wyon et al., 2007).

Another important finding is concerned with the fact that well memorizing abilities can be identified in children by dance talents. Through the educational dance program, teachers can carry out activities to stimulate children's dance talents. The most recent research shows that educational dance activities become an important element of childhood age; variations of training programs are able to improve children's performances (Uspuriene, Malinauskas, \& Sniras, 2019), interventions in targeted dance-based physical activities show a number of indicators of the improvement of creativity in children's work (Neville \& Makopoulou, 2020). Educational dance programs are also able to develop children's brain power (Bugos \& Demarie, 2017; Chatzihidiroglou, Chatzopoulos, Lykesas, \& Doganis, 2018; D’Souza \& Wiseheart, 2018; Karpati, Giacosa, Foster, Penhune, \& Hyde, 2015; Kirsch, Diersch, Sumanapala, \& Cross, 2018; Nim, 2017; Poikonen, Toiviainen, \& Tervaniemi, 2018); it is why results of the evaluation of children's educational dance activities are able to show children's dance talents as they memorize the movement sequences correctly and remember the formation when they need to shift places in the variations of their dance movement. Findings also show that children who like dance activities tend to be bright in the academic field.

Identification of talents that is done just by determining the indicator is related to children's abilities in musicality. The ability to dance with high sensitiveness towards music as a whole and to synchronize between movement and rhythm is an important element for the success of the dancer (Walker et al., 2010). Children with dance talents possess the ability to relate movements to music. They also have the ability to naturally respond to internal or external stimuli using their body, emphasizing the dynamics and tempo of the movements. They have a general sensitivity to music, such as synchronizing the beat of movement and the sound of music or playing the aerophone to the beat of other pieces of music. This musical ability can arise from dance education activities that use audio stimulation, in this case music. The music accompaniment to be selected must be the one that the children like and that stimulate children to do the movements. Some theories have mentioned that children who do not have sensitivity towards music will not be able to become dedicated dancers (Walker et al., 2010).

Children can also be identified as having dance talents, from whether or not they are able to express feelings in the dance. This is although it is quite difficult to record children's expressions of feelings since they all tend to be merry and cheerful when they join the dancing activities or, on the other hand, be playful and not at all serious. Nevertheless, data analyses show that the majority of the children are able to express their feelings quite well. The ability to express feelings is one of the important criteria in the identification of children's dance talents (Critien \& Ollis, 2006; Haroutounian, 2000; Sloboda, 2000). Lutz \& Kuhlman, (2000) state that movement is one of the media of expressions and a first piece of learning about the world and that each new movement gives the children more information about their ability of their body. Bodily movement always becomes a means of communicating feelings and of creative movements in a dance. Through dances, children develop their self-control, especially in reactions towards strong feelings such as anger, fear, and joy.

When children show the high degree of curiosity, are highly enthusiastic about dance 
activities, tend to make adaptation easily, and are willing and open towards new experiences, it can be strongly suggested that they are identified as having dance talents. Dance talents tend to emerge from children who have different personalities from the others. Perfectionism aspects are prominent in children with dance talents, so say Gould, Dieffenbach, \& Moffett (2002) in their stud. The spiritual drives of children with dance talents represent commitment deeper inside, and make the children love dance activities (Gagné, 2007). Theories show that experiences in dance activities have an impact on their talent development since they show positive selfefficacy, self-awareness, commitment, and selfidentify (Walters \& Gardner, 1986).

One very important finding in the present study is that which shows that, while responding to the teacher's stimuli during the educational dance activities, children who are identified as having dance talents tend to show creativities. They show new dance movements, or new unique formation of movement steps emerging from their enthusiasms in the dance activities that they like. They show new movement creations that are coherent and useful (Sternberg, Lubart, Kaufman, \& Pretz, 2005). Children with dance talents tend to be able to find ways to solve problems, think independently, or make a project or product that is original or unusual. They produce an innovative work (create products or intellectual or artistic performance). Dancers are people who have the characteristic of exploring creativity. Research shows that creativity can influence talent development (Subotnik, Edmiston, Cook, \& Ross, 2010). Therefore, it turns out that exploring creativity can be used to identify dance talents.

Motivation is also an important factor in performing a dance and identifying the development of dance talents (Abbott \& Collins, 2004; Walker et al., 2010). In the later findings of the present study, intrinsic motivation is identified as appearing in children with dance talents, which is in agreement with findings of previous studies. A recent cross-sectional study describes that enthusiasm is extremely important in the case of talent development; $100 \%$ musicians and athletes who are in the midst of their talent developments are reported to have very high enthusiasm in their activities (Mageau, Vallerand, Charest, Salvy, Lacaille, Bouffard, \&
Koestner, 2009). This is true in the case of the concepts of intrinsic motivation in the children who are submerged in the educational dance activities. As a whole, motivation is seen as an important element in the consideration of dance talents. Dancers who are intrinsically motivated to find themselves to be oriented to their tasks and are able to evaluate their performance in accordance with a variety of criteria and are apt to pay full attention and efforts to join training and, subsequently, optimize their talents. It is therefore, evident that motivation may become the most important aspect in the identification and development of talents (Walker et al., 2010).

One thing that needs to be noted in the results of the present study is the assumed direction that educational dance activities be included in the school curriculum. Educational dance activities can become a medium not only for the identification of the early phase of dance talents in childhood children, but also for the improvement and stimulation of an important aspect in other children's developmental processes. This is true, especially for the improvement of communicative abilities (Yazejian \& Peisner-Feinberg, 2009), physical, emotional, social, and mental welfares (Theocharidou, Lykesas, Giossos, Chatzopoulos, \& Koutsouba, 2018), and dance training programs using music that will be intimately related to the children's cognitive development as well as reducing children stresses (Sawami, Kimura, \& Kitamura, 2018).

Findings of this study can be expected to be used by teachers and parents as guidelines on the identification of children's dance talents during the early ages, as a practical implication of the study, such us that children is given the best stimulation in developing their dance talents. This is because, besides their own intrinsic motivation within the children. No less important is the aspect of parents' supports that are relevant with talent development and become strong social reinforcements (Holt \& Dunn, 2004; Wolfenden $\&$ Holt, 2005). The socio-economic factors, too, frequently become a determining factor that can hinder children's dance talent development (Ambrose, 2003), including the inadequate fund of the family. Not infrequently, parents need to pay for training fees, buy costumes and musical organs, and travel to and from training venues. It is, of course, true that some talented 
individuals are able to embrace success without financial supports and overcome obstacles and become successful in their talent activities (Gagné, 2007). The role of the peer is no less important for childhood children in their talent development (Van Rossum, 2001). So is that of the teachers'; they have a strong psychological influence towards children who want to develop their dancing skills. Teachers have a strong influential role and feel responsible for the attainment and development of children talents (Walker et al., 2010).

Besides, and in line with the research findings, the teacher is absolutely needed in developing the children's creativity as a model, demo presenter, interactor, scaffolder, and endorser. Activities should be focused not on teacher-initiated ideas, but it must be directed more to support the children's products and learning in creative movements. The teacher must be familiar with creative learning that facilitates the children's creativities. The teacher also must pay attention to the process and product of children's activities. The processbased learning approach gives emphases on the acceptance of every children's creation, supports and appreciation so that children experience satisfaction in creating, and inspiration so that children will be more enthusiastic about create. The teacher must emphasize creative thinking such as originality and encourage the children to their own ideas in their own creative ways. When giving new ideas or activities, the teacher should not do it in a hurry but must give adequate basic knowledge and skills for the children to cope with the new ideas or activities. They should begin from the simple ones and move to the more difficult ones and provide environments that help student's resource to previous knowledge and learning (Cheung, 2010).

Another practical implication arising from the findings of the present study is that the process of stimulation to identify dance talents in children is an audio stimulation process through music and a visual stimulation that becomes extrinsic motivation for children. This is because, according to children, music offers a solution to their feelings; music is everything for them (Fairchild \& McFerran, 2019). So is the case with the visual experiences given by the teacher such as visualization of animals' movements, movements of plantation, and others. All this is important for teachers and parents in order to provide children with movement stimulation to appraise or identify children's talents since talent development occurs whenever children receive the opportunity (Chua, 2014).

\section{CONCLUSION}

The research findings have shown that, of the three educational dance program activities, the audiovisual mode seems to be the better in making easy for teachers and parents to identify childhood children's dance talents. The method or technique of stimulating movements has a strong impact on the identification of the dance talents of childhood children since children of the childhood age are not yet able to formulate a message into dance movements directly and independently. When the movement stimulation is not given correctly, children's movement awareness will not emerge, and their dance talents cannot be detected. When the message is passed clearly, such as by directly looking at objects or viewing videos and pictures (visual), it will be easier for children to imitate the movements in the visual representations into dance movement forms; and, moreover, it will be more expressive if the visual movement is combined with dance musical accompaniment (audio) playing favourite songs. For this, teachers must be able to develop learning programs that give children the opportunity to be involved in creative and enjoyable educational dance activities so that children's dance talents can grow and develop since in the early ages.

\section{REFERENCES}

Abbott, A., \& Collins, D. (2004). Eliminating the dichotomy between theory and practice in talent identification and development: Considering the role of psychology. Journal of Sports Sciences, 22(5), 395408. https://doi.org/10.1080/0264041041 0001675324.

Ambrose, D. (2003). Barriers to aspiration development and self-fulfillment: Interdisciplinary insights for talent discovery. Gifted Child Quarterly, 47(4), 282-294. https://doi. org/10.1177/001698620304700405.

Aujla, I. J., Nordin-Bates, S. M., Redding, E., \& Jobbins, V. (2014). Developing talent among young dancers: Findings from the 
UK centres for advanced training. Theatre, Dance and Performance Training, 5(1), 15-30. https://doi.org/10.1080/19443927 .2013 .877964 .

Baum, S. M., Owen, S. V., \& Oreck, B. A. (1996). Talent beyond words: Identification of potential talent in dance and music in elementary students. Gifted Child Quarterly, 40(2), 93-101. https://doi. org/10.1177/001698629604000206.

Baumol, W. J., Jeffri, J., \& Throsby, C. D. (2006). Making changes: Facilitating the Transition of Dancers to PostPerformance Careers. New York, NY: Advance Project.

Bugos, J. A., \& Demarie, D. (2017). The effects of a short-term music program on preschool children's executive functions. Psychology of Music, 45(6), 855-867. https://doi. org/10.1177/0305735617692666.

Burns, S., \& Harrison, S. (2009). Dance mapping: A window on dance. 2004-2008. London, England: Arts Council of England.

Chatzihidiroglou, P., Chatzopoulos, D., Lykesas, G., \& Doganis, G. (2018). Dancing effects on preschoolers' sensorimotor synchronization, balance, and movement reaction time. Perceptual and Motor Skills, 125(3), 463-477. https://doi. org/10.1177/0031512518765545.

Cheung, R. H. P. (2010). Designing movement activities to develop children's creativity in early childhood education. Early Child Development and Care, 180(3), 377-385. https://doi. org/10.1080/03004430801931196.

Chua, J. (2014). Dance talent development across the lifespan: A review of current research. Research in Dance Education, 15(1), 23-53. https://doi.org/10.1080/146 47893.2013.825749.

Chua, J. (2015). The role of social support in dance talent development. Journal for the Education of the Gifted, 38(2), 169-195. https://doi. org/10.1177/0162353215578281.
Critien, N., \& Ollis, S. (2006). Multiple engagement of self in the development of talent in professional dancers. Research in Dance Education, 7(2), 179-200. https:// doi.org/10.1080/14647890601029584.

D'Souza, A. A., \& Wiseheart, M. (2018). Cognitive effects of music and dance training in children. Archives of Scientific Psychology, 6(1), 178-192. https://doi. org/10.1037/arc0000048.

Fairchild, R., \& McFerran, K. S. (2019). "Music is everything": Using collaborative group songwriting as an arts-based method with children experiencing homelessness and family violence. Nordic Journal of Music Therapy, 28(2), 88-107. https://doi.org/10 $.1080 / 08098131.2018 .1509106$.

Gagné, F. (2007). Ten commandments for academic talent development. Gifted Child Quarterly, 51(2), 93-118. https:// doi.org/10.1177/0016986206296660.

Garces-Bacsal, R. M. (2013). Perceived family influences in talent development among artistically talented teenagers in Singapore. Roeper Review, 35(1), 7-17. https://doi.org/10.1080/02783193.2013.7 $\underline{40598}$.

Giguere, M. (2011). Dancing thoughts: An examination of children's cognition and creative process in dance. Research in Dance Education, 12(1), 5-28. https://doi. org/10.1080/14647893.2011.554975.

Gould, D., Dieffenbach, K., \& Moffett, A. (2002). Psychological characteristics and their development in Olympic champions. Journal of Applied Sport Psychology, 14(3), 172-204. https://doi. org/10.1080/10413200290103482.

Haroutounian, J. (2000). Perspectives of musical talent: A study of identification criteria and procedures. High Ability Studies, 11(2), 137-160. https://doi. org/10.1080/13598130020001197.

Holt, N. L., \& Dunn, J. G. H. (2004). Toward a grounded theory of the psychosocial competencies and environmental 
conditions associated with soccer success. Journal of Applied Sport Psychology, 16(3), 199-219. https://doi. org/10.1080/10413200490437949.

Karpati, F. J., Giacosa, C., Foster, N. E. V., Penhune, V. B., \& Hyde, K. L. (2015). Dance and the brain: A review. Annals of the New York Academy of Sciences, 1337(1), 140-146. https://doi.org/10.1111/ nyas. 12632 .

Kirsch, L. P., Diersch, N., Sumanapala, D. K., \& Cross, E. S. (2018). Dance training shapes action perception and its neural implementation within the young and older adult brain. Neural Plasticity, 2018, 1-20. https://doi.org/10.1155/2018/5459106.

Klein, B., \& Fodor, S. (2019). Talenttiles: A new descriptive talent identification instrument based on teachers' ratings. New Directions for Child and Adolescent Development, 2019(168), 11-25. https:// doi.org/10.1002/cad.20317.

Lidor, R., Côté, J., \& Hackfort, D. (2009). ISSP position stand: To test or not to test? The use of physical skill tests in talent detection and in early phases of sport development. International Journal of Sport and Exercise Psychology, 7(2), 131-146. https://doi.org/10.1080/161219 7X.2009.9671896.

Lutz, T., \& Kuhlman, W. D. (2000). Learning about culture through dance in kindergarten classrooms. Early Childhood Education Journal, 28, 35-40. https://doi. org/10.1023/A:1009595520022.

Mageau, G. A., Vallerand, R. J., Charest, J., Salvy, S. J., Lacaille, N., Bouffard, T., \& Koestner, R. (2009). On the development of harmonious and obsessive passion: The role of autonomy support, activity specialization, and identification with the activity. Journal of Personality, 77(3), 601-646. https://doi.org/10.1111/j.14676494.2009.00559.x.

Martín, C. T., Ric, Á., \& Hristovski, R. (2015). Creativity and emergence of specific dance movements using instructional constraints. Psychology of Aesthetics, Creativity, and the Arts, 9(1), 65-74. https://doi.org/10.1037/a0038706.

McCormack, M., Briggs, J., Hakim, A., \& Grahame, R. (2004). Joint Laxity and the Benign Joint Hypermobility syndrome in student and professional ballet dancers. Journal of Rheumatology, 31(1), 173$178 . \quad$ https://pubmed.ncbi.nlm.nih. gov/14705238/.

Miles, M. B., Huberman, A. M., \& Saldana, J. (2014). Qualitative data analysis: A methods sourcebook ( $3^{\text {rd }}$ ed.). USA: Sage Publication.

Neville, R. D., \& Makopoulou, K. (2020). Effect of a six-week dance-based physical education intervention on primary school children's creativity: A pilot study. European Physical Education Review, 27(1), 203-220. https://doi. org/10.1177/1356336X20939586.

Nim, N. (2017). Dancing to learn: The brain's cognition, emotion, and movement. Body, Movement and Dance in Psychotherapy, 12(3), 227-231. https://doi.org/10.1080/1 $\underline{7432979.2016 .1195448 .}$.

Poikonen, H., Toiviainen, P., \& Tervaniemi, M. (2018). Dance on cortex: Enhanced theta synchrony in experts when watching a dance piece. European Journal of Neuroscience, 47(5), 433-445. https://doi. org/10.1111/ejn.13838.

Sawami, K., Kimura, M., \& Kitamura, T. (2018). Verification of the effect of cognitive training by dance. Clinical and Medical Case Reports \& Studies Research, (02), $1-6$.

Sloboda, J. A. (2000). Individual differences in music performance. Trends in Cognitive Sciences, 4(10), 397-403. https://doi. org/10.1016/S1364-6613(00)01531-X.

Steinberg, N., Hershkovitz, I., Peleg, S., Dar, G., Masharawi, Y., Heim, M., \& SievNer, I. (2006). Range of joint movement in female dancers and nondancers aged 8 to 16 years: Anatomical and clinical 
implications. American Journal of Sports Medicine, 34(5), 814-823. https://doi. org/10.1177/0363546505281805.

Sternberg, R. J., Lubart, T. I., Kaufman, J. C., \& Pretz, J. E. (2005). Creativity. In K. J. Holyoak \& R. G. Morrison (Eds.). Cambridge handbook of thinking and reasoning. Cambridge, England: Cambridge University Press, pp. 351-370.

Subotnik, R. F., Edmiston, A. M., Cook, L., \& Ross, M. D. (2010). Mentoring for talent development, creativity, social skills, and insider knowledge: The APA Catalyst Program. Journal of Advanced Academics, 21(4), 714-739. https://doi. org/10.1177/1932202X1002100406.

Theocharidou, O., Lykesas, G., Giossos, I., Chatzopoulos, D., \& Koutsouba, M. (2018). The positive effects of a combined program of creative dance and braindance on health-related ouality of life as perceived by primary school students. Physical Culture and Sport, Studies and Research, 79(1), 42-52. https://doi. org/10.2478/pcssr-2018-0019.

Uspuriene, A. B. P., Malinauskas, R. K., \& Sniras, S. A. (2019). Effects of education programs on dance sport performance in youth dancers. European Journal of Contemporary Education, 8(1), 136-143. $\quad$ https://doi.org/10.13187/ ejced.2019.1.136.

Van Rossum, J. H. A. (2001). Talented in dance: The Bloom Stage Model revisited in the personal histories of dance students. High Ability Studies, 12(2), 181-197. https:// doi.org/10.1080/13598130120084320.

Walker, I. J., Nordin-Bates, S. M., \& Redding, E. (2010). Talent identification and development in dance: A review of the literature. Research in Dance Education, 11(3), 167-191. https://doi.org/10.1080/1 $\underline{4647893.2010 .527325}$.
Walters, J., \& Gardner, H. (1986). Conceptions of giftedness. In J. Stemberg \& J. E. Davidson (Eds.). The crystallizing experience: Discovering an intellectual gift. New York, NY: Cambridge. University Press, pp. 306-331.

Warburton,E.C.(2002).From talentidentification to multidimensional assessment: Toward new models of evaluation in dance education. Research in Dance Education, 3(2), 103-121. https://doi.org/10.1080/14 $\underline{64789022000050480 .}$.

Williams, K. E. (2018). Moving to the Beat: Using music, rhythm, and movement to enhance self-regulation in early childhood classrooms. International Journal of Early Childhood, 50(1), 85-100. https:// doi.org/10.1007/s13158-018-0215-y.

Wolfenden, L. E., \& Holt, N. L. (2005). Talent development in elite junior tennis: Perceptions of players, parents, and coaches. Journal of Applied Sport Psychology, 17(2), 108-126. https://doi. org/10.1080/10413200590932416.

Wyon, M., Deighan, M., Nevill, A., Doherty, M., Morrison, S., Allen, N., ... \& George, S. (2007). The cardiorespiratory, anthropometric, and performance characteristics of an international/ national touring ballet company. Journal of Strength and Conditioning Research, 21(2), 389-393. https://journals.lww.com/ nsca-jscr/Abstract/2007/05000/THE CA RDIORESPIRATORY,ANTHROPOME TRIC,_AND.17.aspx.

Yazejian, N., \& Peisner-Feinberg, E. S. (2009). Effects of a preschool music and movement curriculum on children's language skills. NHSA Dialog, 12(4), 327-341. https:// doi.org/10.1080/15240750903075255. 